\title{
Pury, a Fine Powder Made From Silkworm Pupae: Utilization and It's Effects on Nutritive Value and Organoleptic Quality of Traditional Snack Foods
}

\author{
Astuti Trina ${ }^{1}$, Kusharto Clara M.K ${ }^{2}$, Muntikah ${ }^{1}$, Amrihati Endang Titi, \\ ${ }^{1}$ Department of Nutrition, Health Polytechnic Jakarta II, Jakarta, Indonesia \\ ${ }^{2}$ Department of Community Nutrition Faculty of Human Ecology, Bogor Agricultural University, Bogor, Indonesia \\ *Corresponding author: kcl_51@yahoo.co.id
}

Received August 01, 2014; Revised September 01, 2014; Accepted September 04, 2014

\begin{abstract}
PURY is a yellowish fine powder made from the silkworm pupae which is a sericultural by-product. It has a well-balanced amount of nutrients (protein and essential amino acids, fats included polyunsaturated fatty acid (PUFA), carbohydrate, vitamins and minerals). The purpose of the study was to utilize and determine the effect of the addition of Pury powder on nutritive value and organoleptic quality of traditional snack foods. The study design was used a randomized block design (RBD) with 3 replications. Organoleptic tests were carried out by 30 semitrained panellists. There are 4 kinds of snacks based Pury developed i.e. Likury, Sempry, Makary, and Krupy. The result of organoleptic tests showed that the majority of the panellists accepts the product with a brownish-yellow colour, less strong aroma, savoury flavour and crunchy. Statistical analysis of Freadman test showed no significant effect exist of the addition of pury flour to a preference level of product, therefore, the snack based pury is expected to be used as an alternative food source of nutrients and later may support food security and eco-friendly programmes.
\end{abstract}

Keywords: pupae, snacks based pury, nutritive value, organoleptic

Cite This Article: Astuti Trina, Kusharto Clara M.K, Muntikah, and Amrihati Endang Titi, "Pury, a Fine Powder Made From Silkworm Pupae: Utilization and It's Effects on Nutritive Value and Organoleptic Quality of Traditional Snack Foods.” Journal of Food and Nutrition Research, vol. 2, no. 9 (2014): 582-586. doi: 10.12691/jfnr-2-9-9.

\section{Introduction}

Indonesia is one of the country with silk-producing centre in some the regions, such as West Java (Jabar), West Nusa Tenggara (NTB) and South Sulawesi (Sulsel) [1]. In 2001-2005 data showed high amounts of Bombyx mori cocoon production but years after the production tends to fluctuate. One of districts in South Sulawesi Province known as the famous producer of silk Bugis is Wajo. In Wajo, 91 of them still productive as silk yarn spinner. Data yarn production in Wajo district, in a year 2013 about $4250 \mathrm{~kg}$. So far, the process of spinning silkworm cocoons into yarn silk produced a huge byproduct is about 29.75 ton pupae every year, which will produce as much as $3421 \mathrm{~kg}$ Pury (11.5\% of pupae). But, if not managed properly will cause pollutant that may affect the health condition of the local community lived in the surrounding of the silk industry centre.

Pupae are the core at the inner part of the cocoon, which commonly through away as a rest in the reeling process of silk production. However, pupae has been used as food in many Asian countries such as Hong Kong, China, Korea and Japan. Reference [2] noticed that are sold commercially as food for animal protein source in soups and sauces, as a special food for heart patient's diet and diabetes due to a low cholesterol content. Where Tussah pupae types are used as cholesterol-lowering drugs and blood pressure because it contains more than $70 \%$ polyunsaturated fatty acids and for hepatitis drug because it contains 36\% essential amino acids [3].

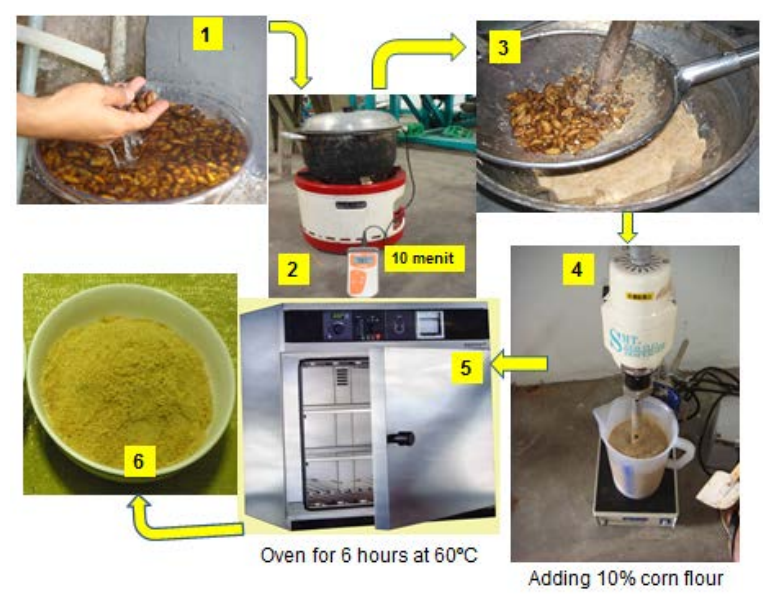

Figure 1. The process of making pury flour [5]

Culturally, acceptability level of mulberry pupae in the eastern part of India reaches $\pm 24.6 \%$ among the age 
group 21-30 years. There are many reasons it's because traditionally been accepted (83.4\%), the taste acceptable (70.3\%), increase the variety of diet $(55.0 \%)$ and $43.9 \%$ for reasons of availability. Although not commonly eaten, any food from locally pupae can be used as a replacement material that has culturally acceptable and high nutritive value and can be used as a potential alternative food for malnourished people [4].

By using a simple processing technique, pupae of Bombyx sp. was extracted and processed into a yellowish fine flour as known Pury (Powder of Pupae Mulberry). It's used as a nutritious basic food source for food and feed which has economic value and eco-friendly. The process of making pury flour followed six steps (e.g. Figure 1) [5].

Pury flour has a potential source of nutrients and physically safe. It is qualified to water level is around $10.4 \%$ which is lower than wheat flour $(12.0 \%)$ [6]. Under these conditions, production of pury can be met the physical qualify safe in terms of moisture content so that the physical, chemical and microbiological damage can be prevented. Meaning that the shelf life of pury becomes longer [5]. Analysis of Pury flour conducted in accredited laboratories to determine the safety and nutrient composition Pury. The methods used include: Bomb Calorimetry, Gravimetry, Titrimetry, Spectrophotometry, Microbiology, and AAS (Table 1 and Table 2).

Table 1. Test Microbial of Pury Flour

\begin{tabular}{|c|c|c|c|}
\hline Parameter & Unit & Level & Analysis Technique \\
\hline Total Plate Count & Colony/g & $5.8 \times 10^{3}$ & Microbiology \\
\hline Coliform & Colony/g & $7.5 \times 10^{1}$ & Microbiology \\
\hline E. Coli & Colony/g & $1.5 \times 10^{1}$ & Microbiology \\
\hline Staphylococcus aureus & Colony/g & Negatif & Microbiology \\
\hline Salmonella / shigella & Colony/25 g & $2.0 \times 10^{1}$ & Microbiology \\
\hline
\end{tabular}

Table 2. The Composition of Nutrients in 100 grams of Pury Flour

\begin{tabular}{|c|c|c|c|}
\hline Parameter & Unit & Level & Analysis Technique \\
\hline Energy & $\mathrm{Cal} / \mathrm{g}$ & 4826 & Bomb Calorimetry \\
\hline Moisture & $\% \mathrm{w} / \mathrm{w}$ & 10.40 & Gravimetry \\
\hline Ash & $\% \mathrm{w} / \mathrm{w}$ & 3.14 & Gravimetry \\
\hline Protein & $\% \mathrm{w} / \mathrm{w}$ & 33.44 & Titrimetry (Kjeldahl) \\
\hline Fat & $\% \mathrm{w} / \mathrm{w}$ & 25.72 & Gravimetry (Soxhlet) \\
\hline $\begin{array}{c}\text { Carbohydrate } \\
\text { Dietary Fiber } \\
\text { Fiber }\end{array}$ & $\begin{array}{l}\% \mathrm{w} / \mathrm{w} \\
\% \mathrm{w} / \mathrm{w} \\
\% \mathrm{w} / \mathrm{w}\end{array}$ & $\begin{array}{l}5.54 \\
0.22 \\
0.71\end{array}$ & $\begin{array}{c}\text { Spectrometry } \\
\text { Gravimetry } \\
\text { Gravimetry }\end{array}$ \\
\hline $\begin{array}{c}\text { Mineral: } \\
\text { Fe } \\
\text { Calcium (Ca) } \\
\text { Zinc (Zn) } \\
\text { Selenium (Se) } \\
\text { Sodium (Na) } \\
\text { Phosphor (P) } \\
\text { Iodine (I) }\end{array}$ & $\begin{array}{l}\text { ppm } \\
\text { ppm } \\
\text { ppm } \\
\text { ppm } \\
\text { ppm } \\
\text { ppm } \\
\text { ppm }\end{array}$ & $\begin{array}{c}30.79 \\
1162.53 \\
95.68 \\
<0.002 \\
300.48 \\
5874.56 \\
45 \\
\end{array}$ & $\begin{array}{c}\text { AAS } \\
\text { AAS } \\
\text { AAS } \\
\text { AAS } \\
\text { Spectrophotometry } \\
\text { AAS } \\
\text { Spectrometry }\end{array}$ \\
\hline $\begin{array}{c}\text { Vitamin: } \\
\text { A } \\
\text { B1 (Thiamin) } \\
\text { B12 (Riboflavin) } \\
\text { Folic Acid } \\
\end{array}$ & $\begin{array}{c}\mathrm{mcg} / 100 \mathrm{~g} \\
\mathrm{mg} / 100 \mathrm{~g} \\
\mathrm{mcg} / 100 \mathrm{~g} \\
\mathrm{mcg} / 100 \mathrm{~g}\end{array}$ & $\begin{array}{c}277 \\
0.66 \\
0.24 \\
68.21 \\
\end{array}$ & $\begin{array}{c}\text { Spectrophotometry } \\
\text { Spectrophotometry } \\
\text { Microbiology } \\
\text { Microbiology } \\
\end{array}$ \\
\hline
\end{tabular}

Utilization of Pury flour for complementary food have been done, in the form of porridge. It has advantages in protein, fats (linoleic and linolenic), vitamins and minerals [7]. Animal assays used Sprague-Dawley feed by purybased ratio 9 g/day for 30 days showed no anatomical abnormalities were identified in internal organs such as liver, kidney, lung, heart, spleen and brain. The results of the study showed a mean weight gain of rats fed Purybased has doubled as compared to the average weight gain of rats fed a commercial formula. A previous intervention program used Pury as complementary food for infant feeding for 3 months in infants underweight aged 6-9 month in Teluknaga, Tangerang, Indonesia showed that a positive increments exist on nutritional status determined by Z-score (Weight for Height) among infants [8]. Therefore, the aims of our study were to observe utilization by-product of pupae silkworm and it's effects on nutritive value and organoleptic quality of traditional snack foods.

\section{Methods}

The study was conducted in October to December, 2010, at Nutrition Department Health polytechnic MOH
Jakarta II. Experimental research design was randomized block design (RBD) [9].

Samples are 4 kinds of snacks-based pury products i.e. Likury, Sempry, Makary and Krupy with 3 times replication of each product. Total sample $=\mathrm{t} \times \mathrm{r}$ formula $=$ $4 \mathrm{x} 3$ replicates $=12$ sample units. P1 is likury with 3 replications with code: 471, 847 and 498; P2 is sempry with 3 replications with code: 581, 460 and 375; P3 is Makary with 3 replications with code: 642, 788 and 137; P4 is krupy with 3 replications with code: 154, 560, and 900.

Number of panellists is 30 people with the inclusion criteria: age 20-40 years, trained/semi-trained as a panellist, willing to be a panellist, not in a state of satiety or hunger, is not involved in the manufacture of the sample, not colour blind, and nonsmokers. Selection of panellists conducted randomly by considering the proportion between male and female panellists. Each panellist was given 4 types of snacks-based pury with 3 times replication for each product. Furthermore, each panellist conducted organoleptic test (gives score) in terms of or colour, aroma, flavour and texture as well as acceptance or general preferences of products and noted on the form sheet available (e.g. Figure 2).. To examine 
the effect of adding pury flour on products produced, performed Friedman test [10], with the formula:

$$
X^{2}=\frac{12}{n \cdot k(k+1)} \sum(R j)^{2}-3 . n(k+1)
$$

Note:

$\mathrm{X}^{2}=$ value of Friedman test;

$\mathrm{n}=$ number of panellists;

$\mathrm{k}=$ number of treatments

$\mathrm{Rj}^{2}=$ number squared value of all treatment

There is an effect of additional pury flour on product quality, when the count value of $\mathrm{X}^{2}$ is greater than the value of $\mathrm{X}^{2}$ table.

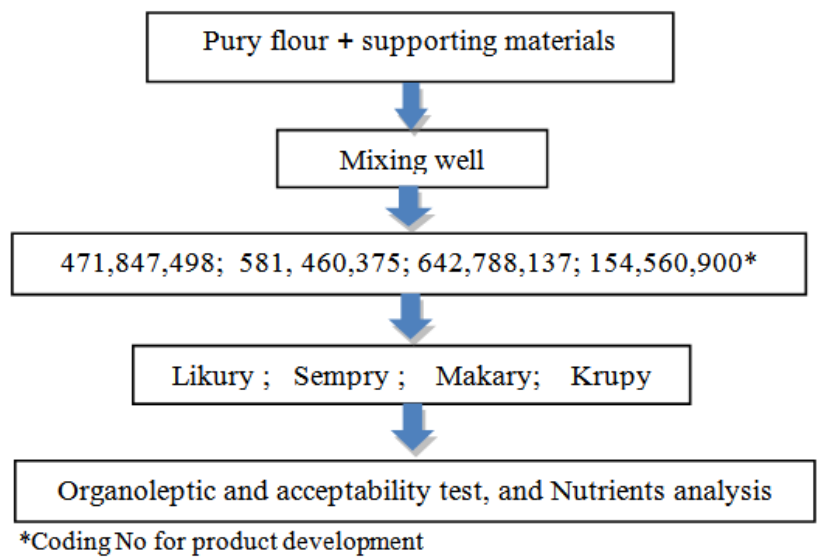

Figure 2. The scheme of analysis (organoleptic, acceptance tests and the nutrients)

\section{Result}

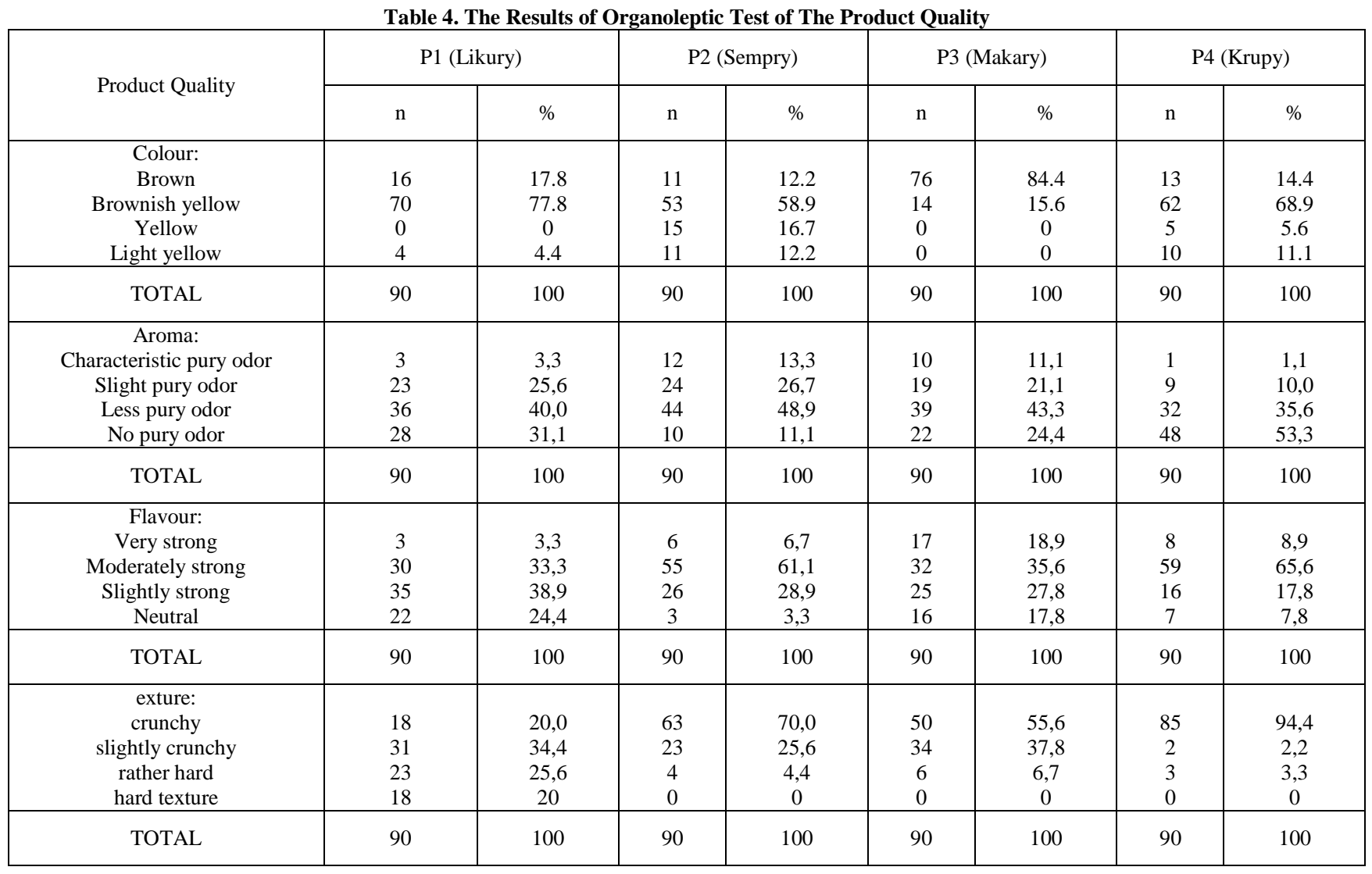

There are 4 kinds of snacks-based Pury were developed in this study i.e. Likury, Sempry, Makary, and Krupy (e.g. Figure 3). And the content of each product showed in Table 3.

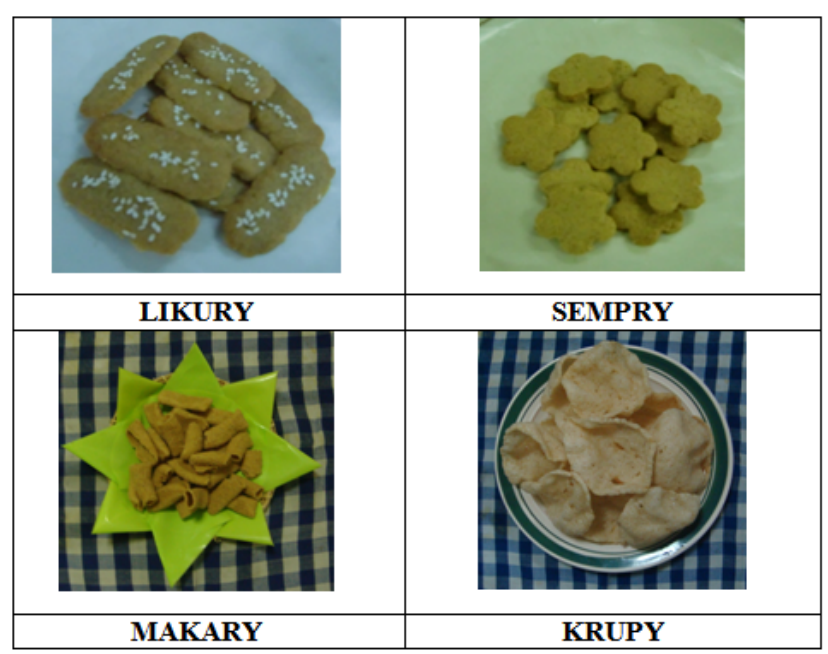

Figure 3. Four snacks-based Pury

Table 3. Energy and Macro-Nutrient Content of Snack-Based Pury

\begin{tabular}{|c|c|c|c|c|c|}
\hline \multirow{2}{*}{ No } & Product & \multicolumn{4}{|c|}{ Energy and nutrient content 100 g of product } \\
\cline { 3 - 6 } & & $\begin{array}{c}\text { Energy } \\
(\text { kkal) }\end{array}$ & $\begin{array}{c}\text { KH } \\
(\mathrm{g})\end{array}$ & $\begin{array}{c}\text { Protein } \\
(\mathrm{g})\end{array}$ & $\begin{array}{c}\text { Fat } \\
(\mathrm{g})\end{array}$ \\
\hline 1. & P1 (Likury) & 467 & 52.1 & 11.5 & 25.9 \\
\hline 2. & P2 (Sempry) & 486 & 53.1 & 12.9 & 27.0 \\
\hline 3. & P3 (Makary) & 509 & 55.8 & 11.7 & 29.0 \\
\hline 4. & P4 (Krupy) & 510 & 67.0 & 4.5 & 19.0 \\
\hline
\end{tabular}

Table 4 shown the results of organoleptic tests in terms of colour, aroma, taste and texture of snack products, while Table 5 shown result of the panellist's acceptability assessment of the product quality.
Table 4. The Results of Organoleptic Test of The Product Quality 
Table 5. A frequency distribution of the panellist's acceptability level of product quality (colour, aroma, flavour and texture)

\begin{tabular}{|c|c|c|c|c|c|c|c|c|}
\hline \multirow{2}{*}{$\begin{array}{l}\text { Panellist's acceptability level } \\
\text { of product quality }\end{array}$} & \multicolumn{2}{|c|}{ P1 (Likury) } & \multicolumn{2}{|c|}{ P2 (Sempry) } & \multicolumn{2}{|c|}{ P3 (Makary) } & \multicolumn{2}{|c|}{ P4 (Krupy) } \\
\hline & $\mathrm{n}$ & $\%$ & $\mathrm{n}$ & $\%$ & $\mathrm{n}$ & $\%$ & $\mathrm{n}$ & $\%$ \\
\hline $\begin{array}{c}\text { Colour }\left(\mathrm{X}^{2}: 25.66\right) \\
\text { Like very much } \\
\text { Like moderately } \\
\text { Like slightly } \\
\text { Dislike } \\
\end{array}$ & $\begin{array}{c}11 \\
43 \\
30 \\
6 \\
\end{array}$ & $\begin{array}{c}12,2 \\
47,8 \\
33,3 \\
6,7 \\
\end{array}$ & $\begin{array}{c}10 \\
55 \\
25 \\
0 \\
\end{array}$ & $\begin{array}{c}11,1 \\
61,1 \\
27,8 \\
0 \\
\end{array}$ & $\begin{array}{c}4 \\
27 \\
46 \\
13 \\
\end{array}$ & $\begin{array}{c}4,4 \\
30,0 \\
51,1 \\
14,4 \\
\end{array}$ & $\begin{array}{c}23 \\
57 \\
9 \\
1 \\
\end{array}$ & $\begin{array}{c}25,6 \\
63,3 \\
10 \\
1,1 \\
\end{array}$ \\
\hline TOTAL & 90 & 100 & 90 & 100 & 90 & 100 & 90 & 100 \\
\hline $\begin{array}{c}\text { Aroma }\left(\mathrm{X}^{2}: 34.26\right) \\
\text { Like very much } \\
\text { Like moderately } \\
\text { Like slightly } \\
\text { Dislike }\end{array}$ & $\begin{array}{c}10 \\
29 \\
44 \\
7 \\
\end{array}$ & $\begin{array}{c}11,1 \\
32,2 \\
48,9 \\
7,8\end{array}$ & $\begin{array}{c}6 \\
33 \\
41 \\
10 \\
\end{array}$ & $\begin{array}{c}6,7 \\
36,7 \\
45,6 \\
11,1\end{array}$ & $\begin{array}{c}9 \\
21 \\
51 \\
9 \\
\end{array}$ & $\begin{array}{l}10,0 \\
23,3 \\
56,7 \\
10,0\end{array}$ & $\begin{array}{c}13 \\
56 \\
15 \\
6 \\
\end{array}$ & $\begin{array}{c}14,4 \\
62,2 \\
16,7 \\
6,7 \\
\end{array}$ \\
\hline TOTAL & 90 & 100 & 90 & 100 & 90 & 100 & 90 & 100 \\
\hline $\begin{array}{c}\text { Flavour }\left(\mathrm{X}^{2}: 82.84\right) \\
\text { Like very much } \\
\text { Like moderately } \\
\text { Like slightly } \\
\text { Dislike } \\
\end{array}$ & $\begin{array}{c}8 \\
30 \\
37 \\
15 \\
\end{array}$ & $\begin{array}{c}8,9 \\
33,3 \\
41,1 \\
16,7 \\
\end{array}$ & $\begin{array}{c}12 \\
36 \\
38 \\
4 \\
\end{array}$ & $\begin{array}{c}13,3 \\
40,0 \\
42,2 \\
4,4 \\
\end{array}$ & $\begin{array}{c}2 \\
20 \\
44 \\
24 \\
\end{array}$ & $\begin{array}{c}2,2 \\
22,2 \\
48,9 \\
26,7 \\
\end{array}$ & $\begin{array}{c}23 \\
52 \\
11 \\
4 \\
\end{array}$ & $\begin{array}{c}25,6 \\
57,8 \\
12,2 \\
4,4 \\
\end{array}$ \\
\hline TOTAL & 90 & 100 & 90 & 100 & 90 & 100 & 90 & 100 \\
\hline $\begin{array}{c}\text { Texture }\left(\mathrm{X}^{2}: 144.27\right) \\
\text { Like very much } \\
\text { Like moderately } \\
\text { Like slightly } \\
\text { Dislike }\end{array}$ & $\begin{array}{c}9 \\
16 \\
34 \\
31 \\
\end{array}$ & $\begin{array}{l}10,0 \\
17,8 \\
37,8 \\
34,4 \\
\end{array}$ & $\begin{array}{c}31 \\
38 \\
16 \\
5 \\
\end{array}$ & $\begin{array}{c}34,4 \\
42,2 \\
17,8 \\
5,6 \\
\end{array}$ & $\begin{array}{c}9 \\
28 \\
40 \\
13 \\
\end{array}$ & $\begin{array}{l}10,0 \\
31,1 \\
44,4 \\
14,4 \\
\end{array}$ & $\begin{array}{c}48 \\
36 \\
6 \\
0 \\
\end{array}$ & $\begin{array}{c}53,3 \\
40,0 \\
6,7 \\
0 \\
\end{array}$ \\
\hline TOTAL & 90 & 100 & 90 & 100 & 90 & 100 & 90 & 100 \\
\hline
\end{tabular}

Acceptance level of panellist to product quality (colour, aroma, flavour and crunchy) of each product (likury, sempry, makary and krupy) and A general rankings based on panellist assessment of product (e.g. Figure 4).

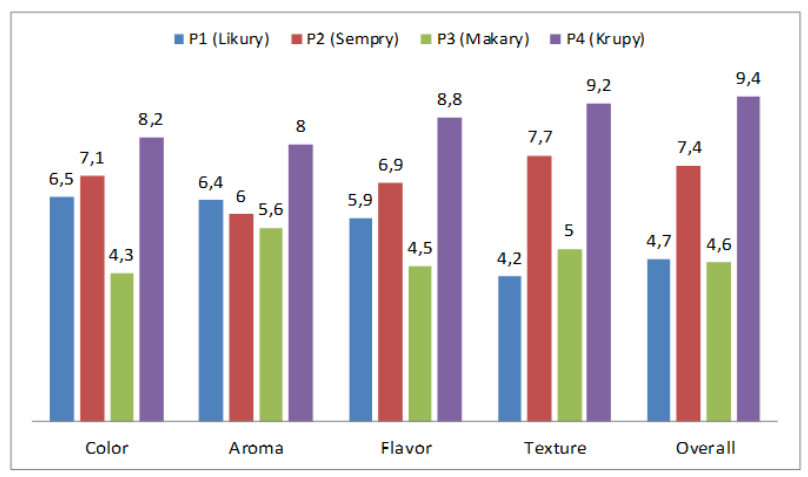

Figure 4. Graphic of products ranking based on panellist' assessment

\section{Discussion}

Based on Table 3 Snacks-based pury products containing energy between 467-510 kcal per 100 grams of product. Composition of macro nutrients in every 100 grams of product is $52-67 \%$ for carbohydrate, 4.5 to $12.9 \%$ for protein and $19-29 \%$ for fat content. Krupy product has the largest of carbohydrate and the smallest protein content as compared to other three products. This is consistent with an supporting material that is mixed with tapioca flour which contains a lot of starch and is not given soybean flour and eggs as a protein source. For product likury, sempry and Makary has energy content, protein and fat are relatively flat at around 400 kilocalories (kcal), 11\% protein and 25\% fat. Regarding the provisions of the Ministry of Health in 2000, the composition of this Pury product in accordance with the energy and nutrient composition of the complementary food, so it can be used as an alternative complementary feeding for children below 2 years old and toddlers.

In Table 4 shows the results of panellists' assessment of the four Pury product stated that the majority of the product is a brownish-yellow colour that is the order of 77.8\% for likury (P1), 68.9\% for crackers (P4) and 58.9\% for sempry (P2), while the colour Makary (P3) the majority of panellist (84.4\%) stated brown. The assessment of the aroma of products, part of panellist stated less Pury odor on likury (P1), sempry (P2) and Makary (P3), and no pury odor at krupy (P4). Assessment of the flavour of products, most panellists expressed moderately strong on sempry (P2), Makary (P3) and krupy (P4), respectively $61.2 \%, 35.6 \%$ and $65.6 \%$ except in likury (P1) around $38.9 \%$ of panellist stated slight strong flavour. Most of the panellists also expressed sempry (P2), Makary (P3) and krupy (P4) product is crunchy respectively $70.0 \%, 55.6 \%$ and $94.4 \%$, except likury (P1) product only $34,4 \%$ of panellist expressed a slightly crunchy.

In Table 5 shows the preference level of panellists for colour, aroma, flavour and texture to four Snacks-based pury products. A level preference of product colour, around $47.8 \%$ of the panellists expressed like moderately of likury (P1), $61.1 \%$ of sempry (P2) and 63.3\% of krupy (P4). Meanwhile, most of the panellists (51.1\%) expressed somewhat like slightly of Makary (P3). Most of the panellists (62.2\%) expressed like moderately towards the aroma of krupy (P4), 48.9\% of panellists expressed like slightly to the aroma of likury (P1), followed by $45.6 \%$ of panellist like slightly the colour of sempry (P2) and 56.7\% like slightly the aroma of krupy (P4). Around $25.6 \%$ of Panellists expressed like very much and 57.8\% like moderately toward flavour of krupy (P4), followed by $40.0 \%$ stated like moderately and $42.2 \%$ like slightly to the flavour of sempry (P2). Around $41,1 \%$ and $48.9 \%$ of panellists expressed like slightly the aroma of likury (P1) and Makary (P3) respectively. According to the 
crunchiness level of the product, most of the panellists like very much and like moderately the products sempry (P2) and Makary (P4) with a percentage of 34.4\%, 42.2\% and $53.3 \%, 40.0 \%$ respectively. To the product crunchiness of Makary (P3), by $31.1 \%$ of panellists expressed like moderately and $44.4 \%$ like slightly. Toward likury product (P1), an amount of $37.8 \%$ of panellists expressed like slightly and of $34.4 \%$ dislike. The Friedman test showed no statistically the effect of adding to the level of preference Pury colour, aroma, flavour and texture with the value of $\mathrm{X}^{2}$ count each parameter greater than $\mathrm{X}^{2}$ table.

The ranking of products specified by giving the order according to the number of samples is 12 , the sample with the number 1 (one) up to the number 12, then scored according to panellists assign existing rankings. Figure 4 shows the rank order in general is krupy, sempry, likury and Makary. The highest rank is Krupy based preference level panellists for colour, aroma, flavour and crunchiness followed by sempry. Meanwhile, likury ranks third and final sequence is Makary. likury have the final sequence based on crunchiness.

\section{Conclusion}

There are 4 kinds of snacks-based Pury developed by utilizing PURY powder, i.e. likury, sempry, makary, and krupy. Snacks-based Pury containing energy 467-510 $\mathrm{kcal} / 100 \mathrm{~g}, 52-67 \%$ carbohydrates, $4.5-12.9 \%$ protein and $19-29 \%$ fat. The result of organoleptic tests showed that the majority of the panellists accepts the product with a brownish-yellow colour, less strong aroma, savoury flavour and crunchy.

Statistical analysis of Friedman test showed that no significant effect exist of the addition of pury flour to a preference level of product quality. At the general preference level of panellists toward the four products as follows the highest rank is Krupy based preference level of panellists, in terms of colour, aroma, flavour, thereafter
Sempry, Likury and Makary. However, Likury have the final sequence based on crunchiness.

\section{Recommendation}

The snack based pury is expected to be used as an alternative food source of nutrients and later may support food security and eco-friendly programmes but it is necessary to conduct the efficacy study prior the next stage of promoting this product.

\section{References}

[1] Kaomini, M. Pengenalan Kegiatan Persuteraan Alam. Puslitbang Hutan dan Konservasi Alam. Bogor. 2006.

[2] Huang Zi-Ran. 2001. Utilization of non-mulberry sericultural resources in China. Int J. Wild Silkmonth \& Silk 6, 91-93.

[3] Mishra, Neelima., N.C.Hazarika, K. Narain, J.Mahanta. Nutritive Value and Cultural Acceptability of Pupae of Mulberry and Nonmulberry Silkworms in Northeast of India. Jurnal Gizi dan Pangan, Juli 20061 (1): 64-65. IPB, Bogor.

[4] Singhal, B.K., Anil Dhar, Aradhana Sharma, SMH Qadri and MM Ahsan. 2001. Sericultural by-products for various valuable commercial products as emerging bio science industry. Sericologia 41 (3) 369-391.

[5] Astuti T. and Clara M. Kusharto. "Using Pury fine powder as an alternative nutritious food”. Jurnal Gizi dan pangan, Maret 20094 (1): 29-32. IPB, Bogor.

[6] Winarno FG. Food and Nutrition Chemistry. PT Gramedia Pustaka Utama. Jakarta. 2004.

[7] Astuti T., Clara M. Kusharto, Hardinsyah, Agus Firmansyah. "Pengembangan MPASI berbasis Pupae-Mulberry (Pury)". Indonesia Nutrition Journal. March 200932 (1): 22-29.

[8] Astuti T. Complementary food development based on pupaemulberry (Pury): Efficacy on the response to growth and motor development among undernourished infants in Teluknaga, Tangerang-Indonesia. Unpublished Dissertation, Bogor Agricultural University. 2009.

[9] Gatchalian, Miflra Minoza. 1989. Assessment and Development. CHE, University of the Philippines Diliman, Philippines.

[10] Siegel, Sidney. 1997. Statistic non-parametric for social science. Jakarta: PT Gramedia Pustaka Utama. 